\title{
Sources of Municipal Incomes in Poland - Current State
}

Prof. PUE, PhD Maria Trojanek

Department of Investment and Real Estate

Poznan University of Economics

r.trojanek@ue.poznan.pl

\begin{abstract}
Own incomes, especially taxes and local charges play the crucial role in a local budget system. By existing regulations local tax revenues are diversified depending on type of municipality, economic basis, local tax policy and other circumstances. District councils have the right to set tax and local charges levels or to introduce tax deductions or tax exemptions. The subject of this study is to analyse local governments' incomes with particular emphasis on municipal incomes.
\end{abstract} Submitted: April, 2010 $1^{\text {st }}$ revision: May, 2010 Accepted: June, 2010

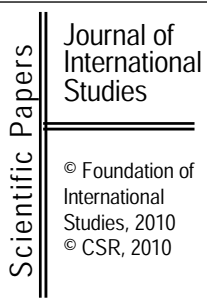

Keywords: municipal incomes, budget system, taxes.

JEL classification: $\mathrm{H} 72, \mathrm{H} 2, \mathrm{P} 2$.

\section{Municipal incomes in light of regulations}

From the point of view being the subject of this paper solution giving frames and legal regulations regarding municipal incomes are of special importance. The most important acts are as follows:

- The Constitution of the Republic of Poland effective since April 2, 1997, that guarantees municipalities to have share in public incomes suitably to tasks;

- Law on local government units incomes of November 13, 2003 (former Law on municipal incomes and rules of subventions - Dz. U. from 1990, No. 89, pt 518 amended; Law on municipalities financing of December 10, 1993 - Dz. U. from 1993, No.129, pt 600 amended; Law on local government units incomes from November 26, 1998 - Dz. U. from 1998, No. 150, pt 983 amended.), where the sources of municipal incomes and rules of their settings and accumulation have been specified $^{1}$,

- Law on local taxes and charges of January $12,1991^{2}$,

- Law on agricultural tax of November $15,1984^{3}$,

- Law on forest tax of October 30, 2002 .

\footnotetext{
${ }^{1}$ Ustawa z dnia 26 listopada 1998 r. o dochodach jednostek samorządu terytorialnego w latach 1999-2001 (Dz. U. z 1998 r. nr 150, poz.983, nr 162, poz. 1 119,2000 r., Dz. U. nr 95, poz.1041) oraz Ustawa z 13 listopada 2003r o dochodach jednostek samorządu terytorialnego (Dz. U. nr 203, poz.1966).

${ }^{2}$ Ustawa z dnia 12 stycznia 1991 r. o podatkach i opłatach lokalnych (t. jedn. Dz. U. z 2006 r., Nr 121, poz. 844), regulująca podatek od nieruchomości, podatek od środków transportowych, opłatę targową, opłatę miejscową oraz uzdrowiskową, jak również fakultatywną opłatę od posiadania psów.

${ }^{3}$ Ustawa z dnia 15 listopada 1984 r. o podatku rolnym (t. jedn. Dz. U. z 2006 r., Nr 136, poz. 969, ze zm.).
} 
Municipal incomes may be classified basing on various criteria. These criteria are not always exact enough and that is the source of various groups of these incomes. Example: the Constitution of the Republic of Poland (Art. 167 section 2 and 3) specifies three types of incomes being a source of financing of local governments. There are own incomes, subventions and subsidies. Constitutional regulations regarding local governments' financing say that:

- local governments' incomes shall be adjusted subject to tasks of individual levels,

- additional tasks are connected with indication of their financial sources and local government units have the right to set tax and local charges levels within the scope presenting in the Constitution.

Law on public finance of August 27, $2009^{5}$ presents the following classification:

- public revenues,

- means from the EU budget,

- non-refundable means from foreign sources,

- incomes of state budget and budgets of local government units,

- incomes of public finance units coming from their activities and other sources.

The most common classification of incomes that occurs in the specialist literature ${ }^{6}$ is as follows:

- own incomes,

- transfers from state budget and from other local government units or out-of-budget sources,

- shares of local government units in tax incomes of the state budget.

Law on local government units incomes contains the specific regulations regarding sources of incomes of local government units. According to Article 3 of this law incomes of local government units are:

- own incomes,

- general subvention,

- grants from the state budget.

Moreover, own incomes (due to the contents of this article) are consisted of shares in incomes from personal and corporate income tax. Own incomes of local government unit shall be:

- non-refundable means from foreign sources,

- means from the EU budget,

- other financial means specified in separate regulations.

According to the law quoted, own incomes of municipalities are:

1) incomes from:

- property tax,

- agricultural tax,

- forest tax,

- vehicle tax,

- personal income tax ,

- tax on dogs,

- inheritance and donation tax,

- tax on civil law entities;

\footnotetext{
${ }^{4}$ Ustawa z dnia 30 października 2002 r. o podatku leśnym (Dz. U. Nr 200, poz. 1682, ze zm.)

${ }^{5}$ Ustawa z dnia 27 sierpnia 2009 r. o finansach publicznych (Dz. U. $2009 \mathrm{nr} 157$ poz. 1240).

${ }^{6}$ Por. P. Swianiewicz, Finanse loklane - teoria i praktyka, Municipum SA, Warszawa, 2004 r., s. 29-31, L. Patrzałek, Finanse samorządowe, Wyd. AE we Wrocławiu, Wrocław 1999 r., s.75 i dalsze, S. Owsiak, Finanse publiczne, PWN, Warszawa 2002 r., s. $341-353$.
} 
2) incomes from:

- stamp duty,

- market charge,

- local charge,

- administrative charge,

- service charge - in part specified in law from February 4, 1994 - Law on geology and mining (Dz. U. No. 27, point 96, amended)

- other municipal incomes paid due to separate regulations;

3) incomes collected by municipal budget units and incomes from municipal budget companies,

4) incomes from municipal possessions;

5) inheritance, bequests and donations to municipality;

6) incomes from fines specified in separate regulations;

7) 5,0\% of incomes for the state budget in connection with government administration tasks and other tasks basing on proper regulations;

8) interest rates from loans granted by municipality unless separate regulations agree otherwise;

9) interest for late payment due being municipal incomes ; unless separate regulations agree otherwise;

10) interest of bank deposits

11) subsidies from budgets of other local government units;

12) $39,34 \%$ share in incomes from personal tax derived from tax payers being municipal residents;

13) $6,71 \%$ share in incomes from corporate tax derived from tax payers having their registered offices in the municipal territory;

14) other incomes due according to separate regulations.

\section{Own incomes of municipalities}

Property $\operatorname{tax}^{7}$ plays the leading role among other local taxes. It is the source of municipal incomes. In the majority of countries capital value (market value of a whole property or a part of property) or rental value (according to market rental prices) form the basis of this tax.

The following properties or buildings are taxable in Poland:

- lands,

- buildings and parts thereof,

- building constructions and part thereof related with conducting business activity,

- lands classified in the land and building records as arable lands, tree- and bush-covered areas in arable lands with business activity.

Owners, holders per se, perpetual users and holders without legal ownership rights are entities of the property tax.

Tax rates are set by a district council and their level cannot be higher than maximal tax rates annually announced by the Minister of Finance. Moreover, a district council can set up tax rates lower than maximal ones and determine other tax exemptions. There is a tax exemption on some properties. For example properties or their parts that serve local government's purposes, construction of public roads, lands under flowing waters and navigable channels, construction and lands used directly for production and transmission of electric energy.

${ }^{7}$ Law on local taxes and charges from January 12, 1991(Dz. U. from 1991, No.9, pt. 84 , amended). 
Due to announcement from August 3, 2009 regarding maximal tax and local charges rates (M. P. No. 52, point 742) real estate tax rates in 2010 are as follows:

1) from land tax:

a) connected with business activity regardless of classification in land records - 0,77 PLN per 1 sq.m,

b) under lakes being retention water bodies or hydroelectric power plants - 4,04 PLN per 1 ha,

c) other lands, including lands occupied to provide payable business activities by charities - 0,39 PLN per 1 sq.m;

2) from buildings and parts thereof:

a) residential - $\mathbf{0 , 6 5}$ PLN per 1 sq.m of usable floor space,

b) connected with business activity and residential buildings or parts thereof occupied to provide business activity - 20,51 PLN per 1 sq.m of usable floor space,

c) occupied to provide business activity within the range of trade of certified seeds - 9,57 PLN per 1 sq.m of usable floor space,

d) occupied to provide health services' business activity -4,16, PLN per 1 sq.m of usable floor space,

e) others, including these occupied to provide payable business activities of charities $\mathbf{6 , 8 8}$ PLN per 1 sq.m of usable floor space;

3 ) from buildings - $2 \%$ of their values calculated due to Article 4 section 1 point 3 and sections 3-7.

The following changes have been introduced from 2003:

- the additional property tax rate for buildings, namely the tax rate on buildings occupied for business activities in providing health care benefits - 3,46 PLN per 1 sq.m of usable floor space;

- instead of creating the possibility of lowering the record by the municipal council to $50 \%$ of the maximum property tax rate, a provision was introduced decisive situations in which the municipal council may vary the rates for different types of taxation. With differential rates of property tax on land (set out in paragraph. 1 pt. 1) the municipal council may include in particular the location, type of operation, type of construction, purpose and method of use. In turn, when determining property tax rates for buildings or parts thereof (referred to in paragraph. 1 pt. 2) the municipal council may vary the amount of items for different types of taxation, in particular regarding the location, method of use, type of construction, condition, age of the building;

- moreover, in determining these rates (except for residential buildings) the municipal council may vary the rates for different types of objects of taxation, in particular regarding the nature of activities.

The rules applicable property tax has been referred to the Law on local taxes and charges. The taxable amount is the area of usable land and buildings. Municipalities have set the upper limit of quota rates (given annually by the Minister of Finance), which are not allowed to exceed. Most municipalities apply the maximum or close to the ceiling. Regardless of location, therefore, the standard of the property, the technical condition of buildings and other relevant characteristics of real estate taxes in the municipality are the same. There is also irrelevant whether this is a newly built hotel with a privileged location or building in a poor state of repair in the provinces. Under the current legal status, albeit of the municipal council are able to differentiate the tax rates are, however, that option is rarely used. It is difficult to create a fair system of differential tax rates.

Agricultural $\operatorname{tax}^{8}$ was introduced in Poland under that name in 1984. Until 1991,

${ }^{8}$ Law on agricultural tax, (Dz. U. from 1984, No. 52 amended.) 
agricultural tax was made up of two part, the tax on agricultural land and agricultural tax revenue from special branches. The entities of agricultural tax are owners and holders of the farm itself. This tax burden on individuals, organizational units having no legal personality. Subject to tax - in accordance with the law - they are farmland with total area of one hectare or arable land with an area exceeding 1 ha rate. The taxable amount is the number of hectares conversion.

Number of hectares of conversion is dependent on:

- type of agricultural land,

- tax districts,

- classes of agricultural land.

Generally accepted principle that, the better the quality of agricultural land, the higher the rate. Conversion of farmland included in the table below

Table 1. Conversion of farmland

\begin{tabular}{|c|c|c|c|c|c|c|c|c|c|}
\hline $\begin{array}{c}\text { Types of } \\
\text { farmland }\end{array}$ & \multicolumn{7}{|c|}{ Arable land } & \multicolumn{3}{c|}{ Meadows and pastures } \\
\hline $\begin{array}{c}\text { Tax districts } \\
\text { Classes } \\
\text { farmland }\end{array}$ & I II & II & IV & I & II & III & IV \\
\hline I & 1,95 & 1,80 & 1,65 & 1,45 & 1,75 & 1,60 & 1,45 & 1,35 \\
\hline II & 1,80 & 1,65 & 1,50 & 1,35 & 1,45 & 1,35 & 1,25 & 1,10 \\
\hline IIIa & 1,65 & 1,50 & 1,40 & 1,25 & & & & \\
\hline III & & & & & 1,25 & 1,15 & 1,05 & 0,95 \\
\hline IIIb & 1,35 & 1,25 & 1,15 & 1,00 & & & & \\
\hline IVa & 1,10 & 1,00 & 0,90 & 0,80 & & & & \\
\hline IV & & & & & 0,75 & 0,70 & 0,60 & 0,55 \\
\hline IVb & 0,80 & 0,75 & 0,65 & 0,60 & & & & \\
\hline V & 0,35 & 0,30 & 0,25 & 0,20 & 0,20 & 0,20 & 0,15 & 0,15 \\
\hline VI & 0,20 & 0,15 & 0,10 & 0,05 & 0,15 & 0,15 & 0,10 & 0,05 \\
\hline
\end{tabular}

Source: Art. 4 pt. 5 Law on agricultural tax

The tax rate expressed as the equivalent of 2.5 quintals of rye for the first three quarters of the year preceding the tax is applied to the hectares of farm livestock.

In this tax exemption in question are used, for example: agricultural land classes $\mathrm{V}$, VI, VTZ, land located in the border belt roads, arable lands and meadows and pastures of reclamation, the land remaining uncultivated land. In addition, taxpayers are entitled to relief in respect of:

- holding the position of the foothills and mountain areas,

- natural disasters,

- acquiring land for the establishment or enlargement of farm, 
- make investments such as the rehabilitation of the environment, the purchase and installation of sprinkler.

Forest $\operatorname{tax}^{9}$ has been introduced in 1992 with the Law on forests. In accordance with binding Law on forest tax from October 20, 2002, entity tax are natural and legal persons and organizational units without legal entity, owning or spontaneous forest owners or holders of forest owned by the State Treasury or local government unit.

The subject of the tax are all forests within the meaning of Article 3 of the Law on forests, with the exception not related to forestry, seized on the holiday resorts, building plots, recreation plots and administrative decisions are excluded from the forest for purposes other than forestry. The taxable amount is the number of hectares of forest conversion, calculated from the surface of the main tree species in the stand and stand grade classes for the main tree species. The tax rate is equivalent to 0.220 cubic meters of coniferous wood sawmill, calculated at the average selling price of wood, obtained by the Superintendence for the first three quarters of the year preceding the tax year.

The share of revenue of $\mathrm{a} / \mathrm{m}$ sources is diverse, in fact depends on the type of community, resource and property type and the scale and characteristics of their operations. In most communities the agricultural tax usually plays a larger role as a source of income in an agricultural communes (rural areas) than, for example property tax. This, in turn, is a major source of income in municipalities where it is located many actors engaged in diversified business activities.

\section{Vehicle tax}

The subject of this tax are natural and legal persons and entities without legal entity owning the means of transportation. ${ }^{10}$ It should be noted that since 1998 there has been a significant narrowing of the scope of this tax. Municipalities have only limited powers in the shaping of the tax. In determining the rates of tax, the municipal council may take into consideration the means of transportation, load, total mass, age and other characteristics (eg. number of seats).

\section{Personal income tax paid in the form of a tax card $^{11}$}

Taxpayers of the income tax paid in the form of a tax card shall be natural persons that lead non-agricultural business activities in such branches as services and crafts (building services, hairdressing, cosmetics etc.), retail trade of foodstuff and others. Natural persons leading service or service-production business activies pay the tax in such form after they place a proper application in the finance office. The amount of income tax in the form of a tax card fixed monthly rate, the amount of which has an impact type of operation, number of employees and number of inhabitants of the locality in which business is carried on.

\footnotetext{
${ }^{9}$ Ustawa z dnia 28 września 1991 r. o lasach (Dz. U. z 1991 r., nr 101).

${ }^{10}$ Por. Ustawa z dnia 12 stycznia 1991 r. o podatkach i opłatach lokalnych, Dz. U. z 1991 r. Nr 9, poz. 31 z późn. $\mathrm{zm}$.

${ }^{11}$ Por Ustawa z 20 listopada 1998 r. o zryczałtowanym podatku dochodowym od niektórych przychodów osiąganych przez osoby fizyczne (Dz. U. 1998 r., Nr 114, poz. 930).
} 


\section{Inheritance and donation tax}

According to Article 1 of the Law on inheritance and donation ${ }^{12}$, acquisition of property objects and property rights in the country by individuals subject to tax on inheritance and donations. The Act lists a number of tax exemptions. The taxable value of the acquired property and property rights after deduction of charges and debts. The value of property and property rights is determined by the state and the rights of those things on the purchase and market prices of tax obligations. The tax payable is determined according to the tax group, which is considered one of the buyer. In each group, the tax was fixed tax-free amount. The inclusion of a specific group (one of three) the tax is made on the basis of the personal relationship of the purchaser to the person from whom or at which they were acquired things, or property rights.

\section{Tax on civil law entities}

With this tax there are taxed transactions mentioned exhaustively, such as, for example: a sales contract, loan agreement, contract, gift, guarantees and other agreements. The taxable amount and rate of tax on civil - legal entities are diverse and dependent on the subject of taxation. The value of the tax is determined on the basis of average prices in the course of things of the same genus and species, including their location, condition and degree of wear, and property rights in the course of the same kind. For example: real estate sales contract is taxed at the rate of tax of $2 \%$, the taxable amount is the average price received for similar properties in that city.

Another source, in addition to taxes, own revenues are fees charged under the Law on local taxes and charges and fees regulated by other laws. Under the Law on local taxes and charges are levied: market, local and administrative.

Market charge ${ }^{13}$ is collected from natural persons, law entities and organisations with no legal entities that sell on local market places. Market charge is collected independently of the charges levied for the use of equipment for fairs and other services provided by the marketplace operator. The maximum rate defined by the Ministry of Finance, while the detailed structure regulates the municipal council.

Charges such as stamp duty, service, adjacent and spatial planning charge are collected under the others laws.

Stamp duty ${ }^{14}$ is paid by natural persons, legal persons, organisation without legal entity if at their request or as a result of the declaration made by them seems to be a certificate or permit or documents. Rates, fees are set by statute. Since this fee is applicable exemption.

Service charge ${ }^{15}$ is an important source of power budgets of the municipalities exploiting mineral deposits. Service charge is paid by the entrepreneur who has a concession to exploit mineral deposits.

Service charge imposes a fee concession-granting authority (governor or the Minister for the Environment). Operating fee revenue is in part a municipality $(60 \%)$ in which business is carried on, and 40\% - income of the National Fund for Environmental Protection and Water Management. The basis for the calculation of the fee is the amount of minerals extracted from the deposit or the amount of material extracted or enriched refined and the sale price of

\footnotetext{
${ }^{12}$ Ustawa z dnia 28 lipca 1983 r. o podatku od spadków i darowizn, Dz. U. z 2004 r., Nr 142, poz. 1514 z późn. $\mathrm{zm}$.

${ }^{13}$ Ustawa z dn. 31 stycznia 1989 r. o opłacie skarbowej, Dz. U. z 1989 r., Nr 4, poz. 23 z późn. zm.

${ }^{14}$ Por. Ustawa z dnia 16 listopada 2006 r. o opłacie skarbowej, Dz. U. z 2006 r., Dz. U. nr 225, poz. 1635 z późn. $\mathrm{zm}$.)

${ }^{15}$ Por. ustawa z dnia 4 lutego 1994 r., Prawo geologiczne i górnicze, Dz. U. Nr 27, poz. 96 z późn. zm.
} 
minerals.

Adjacent charge ${ }^{16}$ - in accordance with Article 4. 1911 Law on Land Management - a fixed fee due to rising property values due to:

- The construction of technical infrastructure equipment grant of the Treasury, local government unit hotel, funds from the EU budget or from foreign sources of nonreimbursable,

- Merge and division of property,

- Division of property.

Establishing and charge depend adiacenckiej property value increase due to the actions mentioned above. The amount of the percentage fee fixed adiacenckiej municipal council by resolution. For example, in the case of property value increase due to the construction of infrastructure, adiacenckiej fee is not more than $50 \%$ of the difference between the value of the property they had before the construction and the value of the property after construction.

(Spatial) planning charge ${ }^{17}$ is charged by the municipality under the Act of 23 March 2003 on planning and land development due to increase in value of property resulting from enactment of local land use plan. In accordance with the provisions of Article. Paragraph 36. 4 this Act, if in connection with the adoption or alteration of the local plan, the increase in the value of real estate, and the owner or perpetual usufructuary sells it, the mayor (mayor or president) takes a one-off charge established in this plan, in an amount not greater than $30 \%$ increase in the value property. Percentage fee planning defines the municipal council. Determination of fees planning can take place within five years from the date on which the local plan or its amendment became applicable.

\section{Subsidies and grants as a source of own income}

Subsidies and grants are the forms of transfer of funds from the central budget to local government units (municipalities, districts, provinces). The difference between the subsidy and the subsidy comes down to this, that the subsidy is not earmarked for a specific purpose. In addition, grants may come from sources other than the state budget. Subsidy is a form of power budgets of local government units and act as regulatory and stimulating. The regulatory function is associated with anti-consolidating, and deepening the disparities associated with:

- uneven distribution of their sources of income,

- efforts to creating the conditions within the country close to meeting basic needs in social infrastructure,

- elimination of need for state differences in the technical infrastructure.

In turn, a function stimulant (stimulates) stems from the fact that the purpose of local government should be - except as to create conditions to meet the needs of residents maintain or take action to increase the number of jobs and expanding the revenue base of a specific territorial unit. General subsidy is divided into three parts:

- equalization - its purpose is to equalize the differences in the performance of tax revenue,

- educational - to fund the tasks of education,

- balancing - the objective is to supplement the income due to changes in the financing of local government tasks.

The allocation of subsidies is based on objective and measurable criteria, described in detail in the law on local government income. Given the large variety of different algorithms for determining the subsidies to local governments, we have omitted in the preparation of

\footnotetext{
${ }^{16}$ Ustawa z dn. 21 sierpnia 1997 r. o gospodarce nieruchomościami, tekst jednolity, Dz. U. z 2004 r., Nr 261, poz. 2603

${ }^{17}$ Ustawa o planowaniu i zagospodarowaniu przestrzennym, Dz. U. Nr 80, poz. 717 z późn. zm.
} 
their presentation. Grants may be awarded from the state budget to finance:

- tasks assigned and entrusted to government administration,

- their current tasks,

- investment.

Delegation of tasks to lower levels of public administration involves the transfer of funds for the funding. The grants are targeted at the task assigned to the parent are important grants to carry out the tasks of government administration. In turn, grants to finance their functions mostly relate to housing benefit payments, feeding students, maintain a special nursery for the municipality.

\section{Conclusion}

Own incomes play the crucial role within the structure of municipal incomes. It has to be added, however, that it is observed the negative process of declining of own incomes' share in total incomes. This is undoubtedly the limitation of the financial autonomy of municipalities and their ability to pursue development goals

\section{Summary}

The study presents the legal conditions of formation of local government revenue at the municipal level. It discusses the sources of income referring to the different criteria present in practice and literature. Relatively more sources of municipalities' income were characterized and especially taxes and local charges. 